\title{
Synthesis and characterization of $\mathrm{Sn}$-doped $\mathrm{TiO}_{2}$ film for antibacterial applications
}

\author{
R. Rajeswari ${ }^{1}$ D. Venugopal ${ }^{1}$ - Amal George ${ }^{2}$ A. Dhayal Raj ${ }^{2}$ S. John Sundaram ${ }^{2}$ - A. K. H. Bashir ${ }^{3,4} \cdot$ M. Maaza $^{3,4}$. \\ K. Kaviyarasu ${ }^{3,4}$ (i)
}

Received: 15 January 2021 / Accepted: 1 June 2021 / Published online: 7 June 2021

(c) The Author(s), under exclusive licence to Springer-Verlag GmbH, DE part of Springer Nature 2021

\begin{abstract}
Simple sol-gel method has been exploited to deposit Sn-doped $\mathrm{TiO}_{2}$ thin films on glass substrates. The resultant coatings were characterized by X-ray diffraction (XRD), UV-visible techniques (UV-Vis), Fourier transform infrared spectroscopy (FTIR), and photoluminescence analysis (PL). The XRD pattern reveals an increase in crystallite size of the prepared samples with the increasing doping concentration. A decrease in doping concentrating resulted in the decrease in bandgap values. The different chemical bonds on these films were identified from their FTIR spectra. The photoluminescence analysis shows an increase in the emission peak intensity with increasing dopant concentration, and this can be attributed to the effect created due to surface states. The prepared samples were tested as antibacterial agent toward both Gram-positive and Gram-negative bacteria like S.aureus (Staphylococcus aureus) and E.coli (Escherichia coli), respectively. The size of the inhibition zones indicates that the sample shows maximum inhibitory property toward E.coli when compared to S.aureus.
\end{abstract}

Keywords Sn-doped $\mathrm{TiO}_{2} \cdot$ Optical properties $\cdot$ Electron microscopy $\cdot$ Antibacterial effect $\cdot$ Dip coating

\section{Introduction}

Investigation on the antimicrobial resistance is a major global issue for last few decades. The importance of antimicrobial resistance has encouraged the arrival of the invention and new effective drugs. The quality of life and health of humankind had improved considerable due to the advent of

R. Rajeswari

rajimrd@ rediffmail.com

K. Kaviyarasu

kaviyarasuloyolacollege@gmail.com

1 Department of Physics, Gobi Arts and Science College, Karattadipalayam Post, Gobichettipalayam, Erode District, Tamil Nadu 638452, India

2 Department of Physics, Sacred Heart College, Tirupattur District, Tamil Nadu 635601, India

3 UNESCO-UNISA Africa Chair

in Nanosciences/Nanotechnology Laboratories, College of Graduate Studies, University of South Africa (UNISA), Muckleneuk Ridge, PO Box 392, Pretoria, South Africa

4 Nanosciences African Network (NANOAFNET), Materials Research Group (MRG), iThemba LABS-National Research Foundation (NRF), 1 Old Faure Road, Western Cape Province, PO Box 722, Somerset West 7129, South Africa antibiotics. Therefore, plants, marine resources and natural origins were used as the source of the invention of novel antibiotics. The process of removing the bacteria or preventing the development of bacterial is known as antimicrobial activity. Through naked eye, the small creature such as microbe is not visible. In the presence of humid and warm conditions, the unicellular bacteria will grow randomly if provided with nutrients [1]. The growth of bacteria can be restricted by using inorganic, organic and organo-metallic compounds such as copper, silver, titanium, and zinc [2-6] that can be made useful without affecting toxic to surrounding tissues. The antimicrobial agents used in the industry are mostly chemically modified natural agents like $\beta$-lactams (like penicillin) and cephalosporin or carbapenems. However, the formation of inheritable resistance may be due to evolutionary process takes place in the antibiotic therapy. As possible mechanisms that lead to bacterial resistance, the conjugation, transduction, or transformation can be cited [7].

\subsection{Aeromonas salmonicida, Escherichia coli, Staphylococcus aureus}

Bacteria, fungi, and viruses cause several disease and health issues in human beings. Among them, bacteria are often 
responsible to cause moderate to severe infections in human beings. Some of the highly virulent bacteria are Aeromonas salmonicida, Escherichia coli, Klebsiella pneumonia, Staphylococcus aureus, , Salmonella paratyphi, Bacillus subtilis and Pseudomonas aeruginosa [8]. The lack of efficient antibiotics and the advent of infectious epidemic diseases have forced the pharmaceutical companies and researchers to look for novel antibacterial agents. The novel search for antibacterial agents includes a wide variety of materials including magnetic materials, semiconductors, noble metals, and their combinations [9]. The semiconductors such as $\mathrm{ZnS}$, CdSe, $\mathrm{InP}, \mathrm{Cds}, \mathrm{TiO}_{2}, \mathrm{ZnO}, \mathrm{CuO}, \mathrm{PbS}$ and $\mathrm{Si}$ are exploited for their antibacterial property [10-14]. Of so many semiconductors available, $\mathrm{TiO}_{2}$ is very often preferred for clinical applications such as to impede bacterial resistance to prevent infections in surgical wounds and burnt patients [15, 16]. Different forms of titania such as 1D nanotubes, 2D thin films, etc., have been studied for their antibacterial properties [17-19]. Doping with different materials have resulted in enhancement of the properties of the host material in applications such as antibacterial, photocatalytic, and optoelectronic. Doping of Sn into host material tends to modify the carrier density of the substance which in turn leads to variation in the efficiency of the prepared products. Materials doped with Sn have been reported to show good antibacterial activity toward cells under test. [20-23]. Wei et al. investigated the effect of light intensity on titanium dioxide ability to utilize bactericidal activity in E. coli. They have reported the number of living cells after a 30-min interval with each intensity, and it shows that the cell's activity decreases with increasing light intensity [25]. Rincon et al. have reported the effect of various chemical parameters on the photocatalytic activity of E. coli $\mathrm{K} 12$ with $\mathrm{TiO}_{2} \mathrm{P}-25$ Degussa as a catalyst. The effect of chemical compounds on photocatalytic disinfection has also been studied by the addition of bacterial suspension on compounds, phosphate buffer, and tap water [24]. Water treatment using $\mathrm{TiO}_{2}$ semiconductor as photocatalyst was discussed by Liu et al. They have mentioned that $\mathrm{N}$-doped $\mathrm{TiO}_{2}$ has revealed higher photocatalytic activity in bacterial production and chemical degradation [26, 27]. Guillard et al. have worked on microbiological disinfection of water and air by photocatalysis, and they have done an experimental study that is accomplished by utilizing dialysis membranes to examine the outcome of relations amongst microorganisms and photocatalyst and to determine the role of situreleased $\mathrm{H}_{2} \mathrm{O}_{2}$ [28] . Wu et al. have also investigated and reviewed the conversion processes, and they came to know that it is connected to the light-induced reactivity of oxide semiconductors vs. water [29].

Many methods such as the sol-gel method, solvothermal process, ion implantation method, chemical vapor deposition, and reverse microemulsion method have been used for the synthesis of $\mathrm{TiO}_{2}$ [29-31]. Various modification has been introduced to improve the antimicrobial properties and photoactivity of titanium photocatalyst in UV-visible irradiation. One among those methods is surface doping with nanoparticles, noble metals, metal oxides (e.g., $\mathrm{ZnO}, \mathrm{WO}_{3}, \mathrm{SiO}_{2}$ ), and nonmetals [32]. The light absorption of $\mathrm{TiO}_{2}$ can be extended into the visible range by doping with transition metal ions or/and with anions. More recently, a suggested solution for the energy-harvesting of visible light is the deposition of noble metal nanoparticles onto the surface of a semiconductor, to form a metal-semiconductor composite photocatalyst [33-35]. A metal-based antimicrobial agent has been studied more extensively. However, metal ions are important for living organisms. Therefore, it might be more suitable for antibacterial application [36-38]. Alternatively, nonmetal elements doping seems to be more successful in antibacterial [39]. In this study, sol-gel method is employed to deposit Sn-doped $\mathrm{TiO}_{2}$ thin films on glass substrates to feasible maximum antibacterial activity. We could control the structure and optical properties by varying the doping concentration in different percentages. The properties of the deposited films are investigated using different characterization methods.

\section{Experimental procedure}

The titanium (IV) isopropoxide (TTIP) (molecular weight (M.W) $284.22 \mathrm{~g} / \mathrm{mol}$ ) with $97 \%$ purity, ethanol with $96 \%$ purity (M.W: $46.07 \mathrm{~g} / \mathrm{mol}$ ), and tin (II) chloride dihydrate with $98 \%$ purity (M.W: $225.65 \mathrm{~g} / \mathrm{mol}$ ) were purchased from Merck, India. The sol-gel method was used to prepare the Sn-doped $\mathrm{TiO}_{2}$ thin films. In a typical synthesis of Sn-doped $\mathrm{TiO}_{2}$ thin films, titanium (IV) isopropoxide (TTIP) was added into ethanol under constant stirring. Meanwhile, tin chloride at different molar ratios to form $1 \%, 3 \%$, and $5 \% \mathrm{Sn}$ doping was added into the solution containing ethanol and deionized water. After stirring for $1 \mathrm{~h}$, few drops of nitric acid were added to maintain $\mathrm{pH}$ around 3 . The final solution is stirred until a transparent yellow solution is obtained. The sol-gel dip coating technique is used to deposit Sn-doped $\mathrm{TiO}_{2}$ thin films at room temperature (RT). The pre-cleaned glass substrates are kept immersed in the final solution for $10 \mathrm{~min}$ and then withdrawn slowly to avoid unpleasant ramp. Then, the coated substrates are left in normal atmosphere for $5 \mathrm{~min}$ to be vertically dried. The same procedure is followed for 10 times, and the final films are annealed at $450{ }^{\circ} \mathrm{C}$ for $1 \mathrm{~h}$. The deposited films are subjected to various studies.

\subsection{Antibacterial activity}

\subsubsection{Sterilization of glass ware}

The chromic acid solution is prepared by mixing $10 \%$ potassium dichromate solution in $25 \%$ concentrated sulfuric acid. The glassware is soaked overnight in chromic acid solution 
and then rinsed repeatedly in distilled water and dried in a hot air oven. Glassware thus cleaned is sterilized in an autoclave at $120^{\circ} \mathrm{C}$ with a pressure of $1.034 \times 10^{3}$ mbar for $20 \mathrm{~min}$

The chromic acid solution is prepared by mixing $10 \%$ potassium dichromate solution in $25 \%$ concentrated sulfuric acid. The glassware is soaked overnight in chromic acid solution and then rinsed repeatedly in distilled water and dried in a hot air oven. Glassware thus cleaned is sterilized in an autoclave at $120^{\circ} \mathrm{C}$ with a pressure of $1.034 \times 10^{3} \mathrm{mbar}$ for $20 \mathrm{~min}$.

\subsubsection{Disc diffusion test}

The disk diffusion test is one of the best methods to check the antibacterial property of the deposited films against bacteria. It is also called as the agar diffusion test or Kirby-Bauer (KB) test. In this method, the prepared samples are subject to test the extent to which they affect the growth of bacteria. Herein, the bacterial culture is suspended in the buffer and applied uniformly across a petri dish or culture plate. The media used in the current agar-diffusion test are a mixture of beef infusion $(300 \mathrm{gm} / \mathrm{lit})$, agar $(17 \mathrm{gm} / \mathrm{lit})$, acid hydrolysate of casein $(17 \mathrm{gm} / \mathrm{lit})$ and starch $(1.5 \mathrm{gm} / \mathrm{lit})$. The $\mathrm{pH}$ of the solution thus obtained was $7.4 \pm .2$ at $25{ }^{\circ} \mathrm{C}$. The solution was filled in a petri dish, and the bacteria were cultured on this medium. The petri dish in which bacteria are placed is taken, and the prepared samples are placed in different wells at various concentrations. This plate is left undisturbed for incubation and growth of the bacteria. No colonies of bacteria are witnessed around the well in which the sample concentration is equal to or greater than the MIC. MIC is the abbreviation of minimum inhibitory concentration and represents the details about the minimum concentration of the prepared sample which is effective against the bacterial growth. If our sample has antibacterial property (good antibiotic), it stops the bacterial growth or kills the bacteria approaching the well. Hence, there will be an area around the well wherein there is no visible growth of bacteria. This zone is called as the inhibition zone or the zone of inhibition. After measuring the diameter of the inhibition zone, the values must be compared with the earlier reported values to check whether the bacterium under consideration for study is susceptible or a little susceptible or resistant to the prepared sample. Smaller MIC of the prepared samples will result in larger inhibition zones with greater diameter. The extent of the inhibition zone depends on the following two factors;

(i) The effectiveness of the prepared sample in stopping the growth of the bacterium.

(ii) The diffusion ability of the prepared sample within the agar medium [40].
For analyzing the bacteriostatic activity of the prepared samples, $1 \mathrm{mg}$ of the sample was stirred with $5 \mathrm{~mL}$ bacterial suspension in saline solution and required amount (20, 40, and $90 \mu \mathrm{l}$ ) of the test suspension containing the sample was filled in the wells in the petri dish that was incubated for bacterial growth at $37^{\circ} \mathrm{C}$ for $24 \mathrm{~h}$.

\section{Results and discussion}

\subsection{Structural analysis}

The crystallite structure and the phase purity of the deposited $\mathrm{Sn}$-doped $\mathrm{TiO}_{2}$ thin films are investigated using X-ray diffractometer (XRD). The structural parameters of the prepared thin films were analyzed at room temperature using Philips X'PERT X-ray diffractometer using CuK $\alpha$ radiation. An anatase phase $\mathrm{TiO}_{2}$ doped with $1 \%, 3 \%$, and $5 \% \mathrm{Sn}$ is revealed from the XRD peaks presented in Fig. 1. The position of the XRD peaks matches well with those reported in JCPDS card no: 21-1272. The peak corresponding to (101) plane increases with increasing doping percentage. The $1 \%$ Sn-doped sample shows reduced peak intensity which may have raised due to restriction in the mobility of oxygen and titanium atoms. Similar results have been reported by Nejand et al. [41]. Huang et al. [42], have reported an increase in the peak intensity of the $3 \%$ Sn-doped sample due to the inclusion of $\mathrm{Sn}^{4+}$ into $\mathrm{TiO}_{2}$ lattice. This in turn affects the stabilization effect on the crystalline structure during the nucleation of anatase $\mathrm{TiO}_{2}$. The intensity of peak corresponding to (101) plane increases along with the low intensity representations for anatase peaks corresponding to (004) and (200) planes in the 5\% Sn-doped $\mathrm{TiO}_{2}$ samples that the doping of $\mathrm{Sn}$ has favored the crystallite along (101) plane [43]. The crystallite sizes as calculated from the

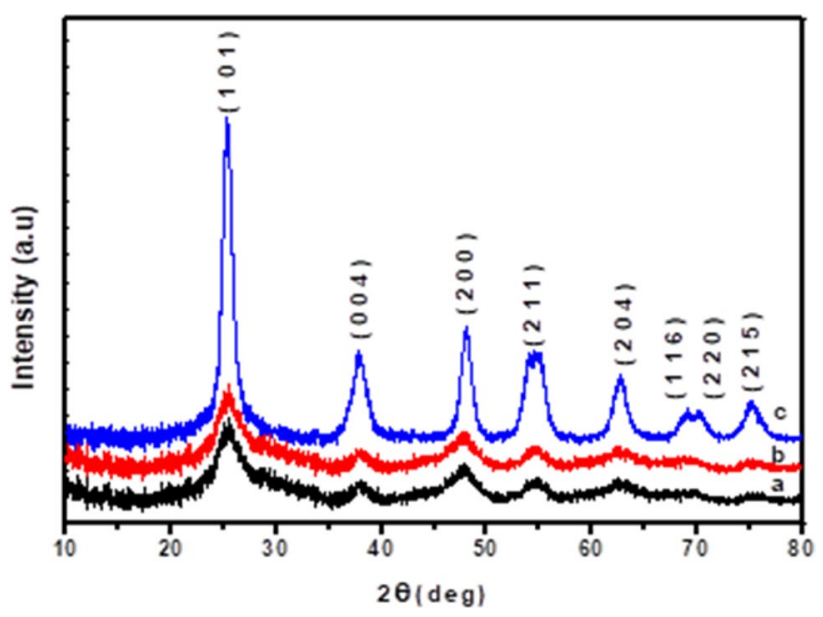

Fig. 1 XRD pattern of $\mathrm{Sn}$-doped $\mathrm{TiO}_{2}$ thin films for different doping percentages like a $1 \%, \mathbf{b} 3 \%$, and c $5 \%$ 
Scherrer's formula yield a value of $3.27 \mathrm{~nm}, 3.88 \mathrm{~nm}$, and $7.75 \mathrm{~nm}$ for different doping percentages like $1 \%, 3 \%$, and $5 \%$ for (101) plane, respectively. It shows that the crystallite size of anatase phase increases when the doping concentration increases from 1 to $5 \%$ [44].

\subsection{Optical analysis}

The optical absorption spectra of the prepared thin films were recorded using VARIAN CARRY $50 \mathrm{UV}-$ Vis spectrophotometer. The UV-Vis optical absorption spectra in Fig. 2 correspond to the $\mathrm{Sn}$-doped $\mathrm{TiO}_{2}$ thin films. From the graph, it is evident that with increasing dopant concentration, the absorption edge shifts toward longer wavelength. This in turn reveals a reduction in bandgap value. Earlier report supports this result with the interpretation that intermediate energy levels are formed due to doping and this results in decrease in bandgap on doping metals into $\mathrm{TiO}_{2}$ [45]. The $(\alpha h v)^{1 / 2}$ Vs (hv) graph is plotted to calculate the bandgap value of the prepared samples and presented in Fig. 2. It is clearly seen that the bandgap values calculated from the Tauc plot are $3.63 \mathrm{eV}, 3.25 \mathrm{eV}$, and $3.05 \mathrm{eV}$ for $\mathrm{TiO}_{2}$ thin-film samples doped with $1 \%, 3 \%$, and $5 \%$ Sn, respectively. From Fig. 2, it is clearly seen that the bandgap of the samples decreases from $3.63 \mathrm{eV}$ to $3.05 \mathrm{eV}$ with increasing dopant concentration. Thus, lower energy is required to excite an atom from valence band to conduction band in the sample doped with 5\% Sn when compared to $\mathrm{TiO}_{2}$ doped with $1 \% \mathrm{Sn}$ [46]. The bandgap value reported earlier for bulk $\mathrm{TiO}_{2}$ is $3.2 \mathrm{eV}$. This value is lower when compared to those obtained in the current study which indicates the smaller grain size. The prepared $\mathrm{Sn}$-doped $\mathrm{TiO}_{2}$ samples exhibit an indirect bandgap which seem to have been red-shifted from their undoped parent material due to incorporation of the dopant. The Sn doping leads to substantial improvement in the semiconducting applications [47-49].

\subsection{Vibrational analysis}

The presence of the various functional groups was studied using a PerkinElmer Fourier transform infrared spectrophotometer in the frequency range $4000 \mathrm{~cm}^{-1}$ to $400 \mathrm{~cm}^{-1}$ under transmission mode of operation. Figure 3 projects the Fourier transformed infrared spectra of $\mathrm{TiO}_{2}$ thin-film samples with (a) $1 \%$, (b) $3 \%$, and (c) $5 \%$ Sn doping. The broadband around $3410 \mathrm{~cm}^{-1}$ and a smaller band around $1645 \mathrm{~cm}^{-1}$ reveal the presence of surface bonded hydroxyl group vibrations which may be interpreted as due to adsorbed moisture [50]. The vibrations corresponding to $\mathrm{Sn}-\mathrm{O}-\mathrm{Sn}, \mathrm{Ti}-\mathrm{O}-\mathrm{Ti}$, and $\mathrm{Ti}-\mathrm{O}-\mathrm{Sn}$ bonds are witnessed in the region between 400 and $800 \mathrm{~cm}^{-1}$ [51]. The vibrations pertaining to hetero$\mathrm{Ti}-\mathrm{O}-\mathrm{Sn}$ bond $[49,50]$ is seen around $1030 \mathrm{~cm}^{-1}$.

\subsection{Photoluminescence analysis}

The photoluminescence properties of the prepared Sn-doped $\mathrm{TiO}_{2}$ thin films have been investigated by recording room temperature PL spectrum using FLS1000 spectrometer. The samples were excited at a wavelength of $300 \mathrm{~nm}$, and their emission characteristics were studied. The PL emission spectra of $\mathrm{Sn}$-doped $\mathrm{TiO}_{2}$ thin films are shown in Fig. 4. The peaks of these samples centered at $391 \mathrm{~nm}[52,53]$ have been ascribed to the band-edge transitions of anatase crystalline $\mathrm{TiO}_{2}$. The emission peaks may have arisen due to the surface states created because of oxygen vacancies and defects on the surfaces of films rather than direct transition from valence to conduction band. Earlier reports reveal that the excitonic peak intensities become stronger with the reduction in particle size. Also, an appropriate amount of dopant can suppress the recombination of electron and holes created due to excitation energy. However, new recombination centers for electron-hole pairs can be created with excess number of dopants [53].
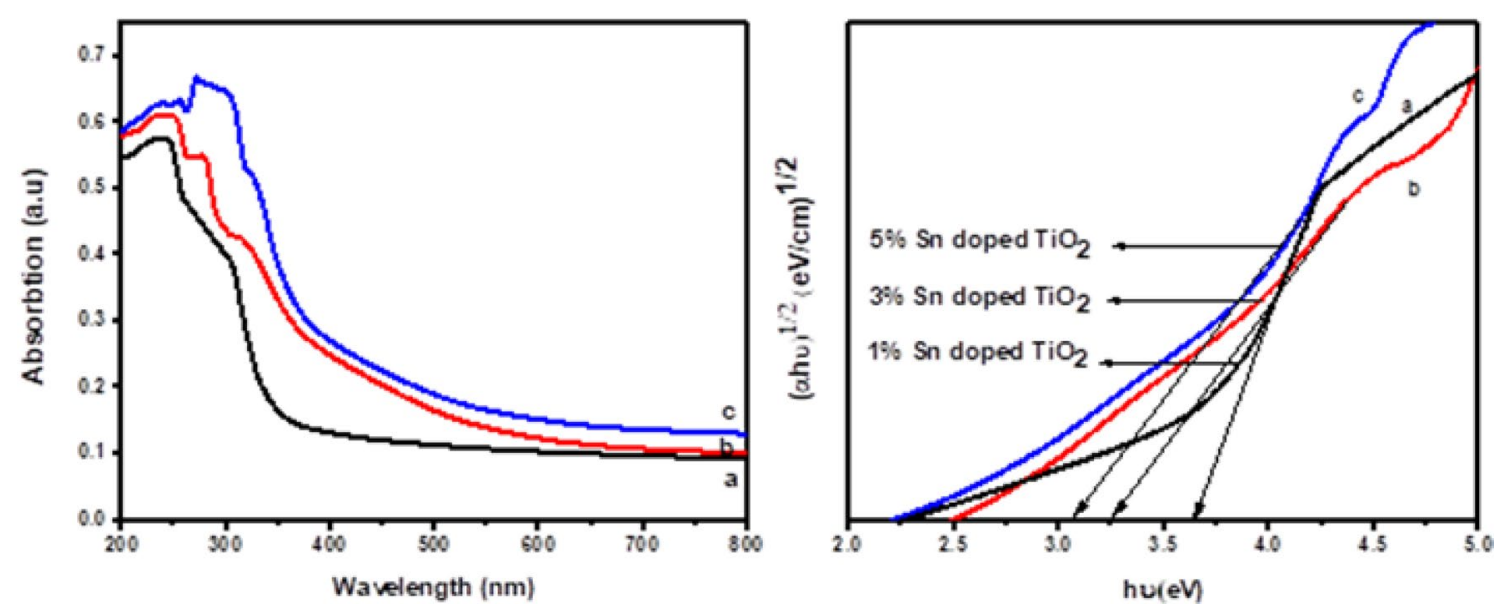

Fig. 2 Absorption and Tauc plot spectrum of Sn-doped $\mathrm{TiO}_{2}$ thin films prepared with different doping percentages like a $1 \%$, b 3\%, and c 5\% 


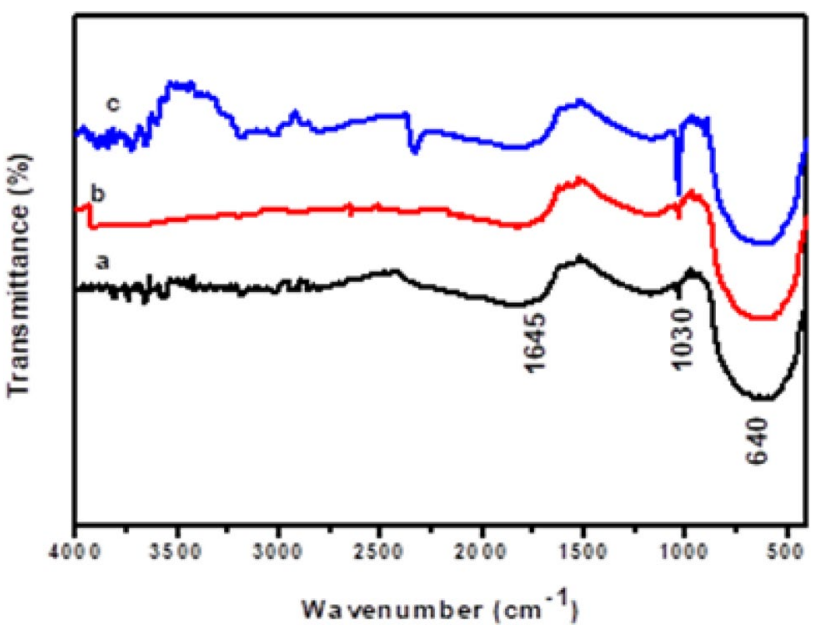

Fig. 3 FTIR spectra for Sn-doped $\mathrm{TiO}_{2}$ thin films prepared with different doping percentages like a $1 \%$, b $3 \%$, and c $5 \%$

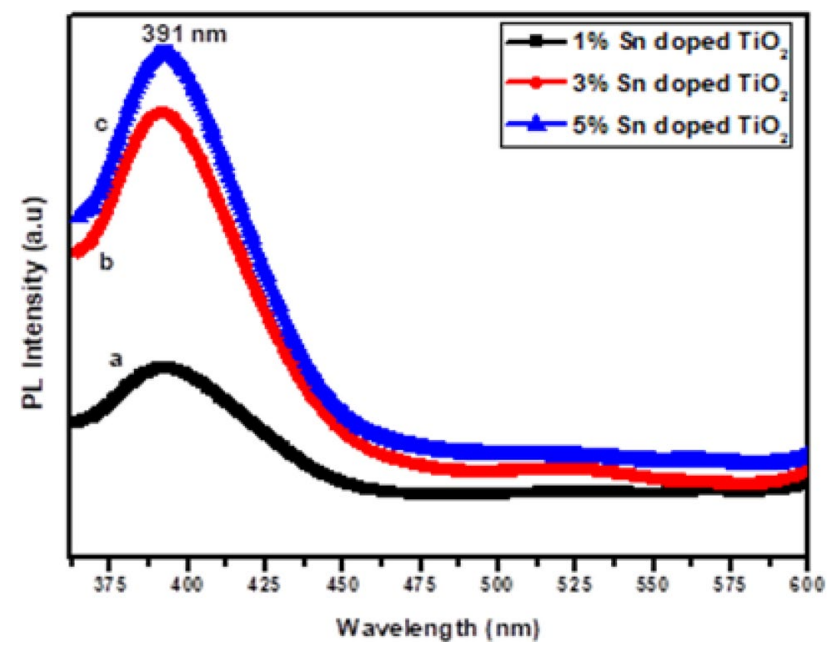

Fig. 4 Photoluminescence spectra for $\mathrm{Sn}$-doped $\mathrm{TiO}_{2}$ thin films prepared with different doping percentages like a $1 \%, \mathbf{b} 3 \%$, and c $5 \%$

\subsection{Surface morphological analysis}

The effect of doping $\mathrm{Sn}$ into $\mathrm{TiO}_{2}$ influences the morphology of the prepared films that are investigated using SEM. The surface morphology of the samples was studied using the JEOL InTouch Scope series JSM-IT500HR model scanning electron microscope. Figure $5(\mathrm{a}-\mathrm{c})$ shows the SEM micrographs of $\mathrm{TiO}_{2}$ thin films with $1 \%, 3 \%$, and 5\% Sn doping, respectively. The SEM images clearly indicated that with increase in Sn doping percentage, the surface roughness of the films also increases. For doping with lower concentration of Sn, particles like formation are seen on the surface of the film. It was witnessed that the mean grain size of the films increases suggestively, while doping percentage increases. At low doping percentage, numerous nucleation centers are present over the substrate and small crystals are formed. The average particle sizes are $46 \mathrm{~nm}$ and $60 \mathrm{~nm}$ for $1 \%$ and 3\% Sn-doped films, respectively. But on doping with 5\% Sn, the particles get agglomerated on the surface of the film to form island-like structures that seem to increase the surface roughness of the films. The killing capacity of the Sn-doped $\mathrm{TiO}_{2}$ could be estimated without the interference of the additional factors through agar diffusion test [54].

\subsection{Antibacterial activities of the prepared samples}

The prepared samples were tested as antibacterial agent, toward different bacteria strains using disk diffusion technique. The growth inhibition property of the samples over different bacterial strains was studied. The cell walls of different bacterial strains exhibit different properties. For instance, a thin cell wall is noticed in Gram-positive bacteria, whereas the Gram-negative bacteria possess very thin walls. Thus, the extent to which the sample prohibits the growth of these bacteria or kills them varies accordingly [55]. The lowest concentration of the prepared sample that prevents the visible growth of bacteria is termed as minimum inhibitory concentration (MIC). The MIC of the prepared sample is determined by preparing solutions of the sample at increasing concentrations and incubating
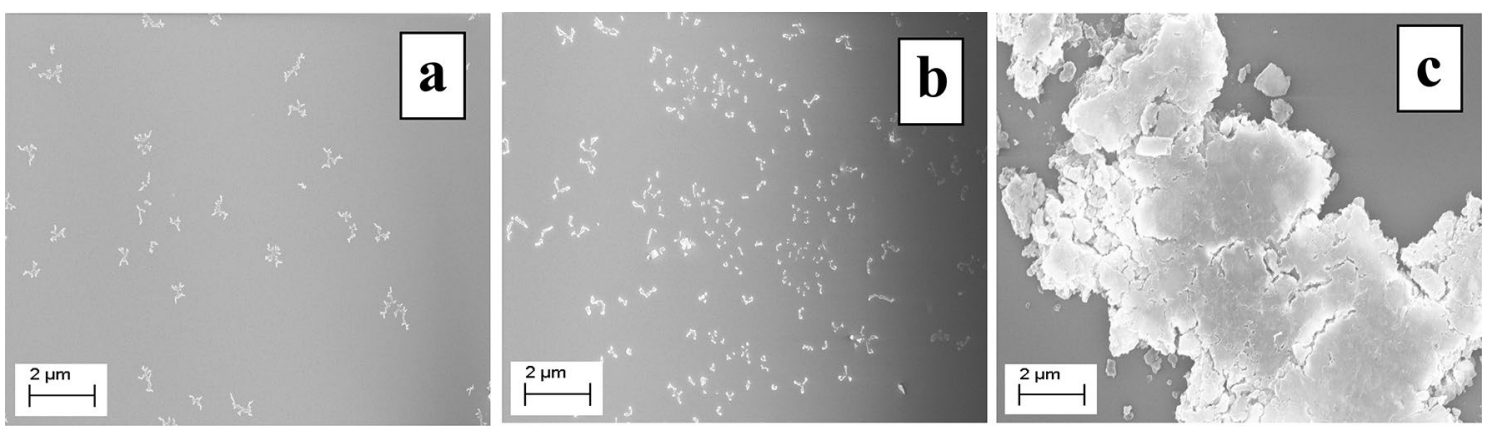

Fig. 5 SEM images for Sn-doped $\mathrm{TiO}_{2}$ thin films prepared with different doping percentages like a $1 \%$, b $3 \%$, and c $5 \%$ 
the sample solutions with separate batches of cultured bacteria using agar disk dilution method. MIC is used to determine which concentration of the prepared sample is sensitive (S), intermediate (I), or resistant (R). The information regarding MIC acts as a guide to any clinician to take decisions on the susceptibility of any bacteria to the antibacterial agent and helps in treatment. The sample that prevents the growth of bacteria or keeps them in stationary phase of growth is termed as bacteriostatic, whereas those samples that kill the bacteria are called bactericidal. The clinical importance of $\mathrm{Sn}$-doped $\mathrm{TiO}_{2}$ bactericidal effect and bacteriostatic effect on different bacteria is under argument as $\mathrm{TiO}_{2}$ exhibits both bactericidal and bacteriostatic properties $[56,57]$. The images of the culture plate on which S.aureus and E.coli are grown are presented in Fig. 6. Each culture plate contains different concentrations of the prepared $\mathrm{Sn}$-doped $\mathrm{TiO}_{2}$. An inhibition zone is as if the antibiotic stops the bacteria from growing or killing the bacteria, there will be an area around the disc where the bacteria are not grown enough to be seen [58]. The inhibition zone is clearly visible around each well, and this in turn suggests the extent to which the sample concentration in the corresponding well hinders the bacterial growth. The effect of prepared samples on E.coli and S.aureus is measured for three different concentrations, and the results are presented in Table 1. On comparing the results obtained, it is clearly evident that the sample shows maximum inhibitory property toward E.coli when compared to S.aureus. The wells indicated as a, b, and c for each sample contained $\mathrm{Sn}$-doped $\mathrm{TiO}_{2}$ samples with $1 \%, 3 \%$, and 5\% Sn doping, respectively. The diameter of the zone of inhibition increased with increasing sample concentration as can be seen from Fig. 6. This in turn suggests that as Sn doping is increased, the number of free charge carriers is also increased. This in turn suppresses the growth of bacterial strains to greater extent by breaking up of cell wall membrane. This concept is supported
Table 1 Comparison of the diameter of zone of inhibition for different samples

\begin{tabular}{llll}
\hline Sample name & $\begin{array}{l}\text { Sample concen- } \\
\text { trations }\end{array}$ & $\begin{array}{l}\text { Zone of inhibition in } \mathrm{mm} \\
\text { toward }\end{array}$ \\
\cline { 3 - 4 } & & $\begin{array}{l}\text { Staphylococcus } \\
\text { aureus }\end{array}$ & $\begin{array}{l}\text { Escher- } \\
\text { ichia } \\
\text { coli }\end{array}$ \\
\hline Sn-doped $\mathrm{TiO}_{2}$ & $20 \mu \mathrm{L}$ & 15 & 22 \\
& $40 \mu \mathrm{L}$ & 20 & 31 \\
& $90 \mu \mathrm{L}$ & 25 & 38 \\
\hline
\end{tabular}

by the results obtained in our study, i.e., the E.coli with thinner cell wall being destroyed to greater extend. A comparison of the antibacterial property of $\mathrm{Sn}$-doped $\mathrm{TiO}_{2}$ for different concentrations toward the different bacterial strains is presented in Fig. 7. The sample exhibits better reactivity toward negative bacterial strains of E.coli [59-63]. Free radicals produced in the surface of the semiconductor when irradiated with light are responsible for destroying the outer cell wall of the bacteria cultured. This prevents the overgrowth of bacteria in nearest vicinity of the semiconductor material placed in the wells inside the petri dish. However, direct kinetics is estimated by investigating the surface area of the semiconductor, the amount of photon absorption, the level of microbial contamination, and eventually the number of free radicals. Unlike strains have different external structures and therefore should display different extents of reactivity under photocatalytic environments [64, 65]. $\mathrm{TiO}_{2}$ has an extremely strong oxidation potential and can therefore destroy bacteria to a greater extend [66]. Nevertheless, there is no obvious link among the cell wall features of the bacteria and the killing ability as high and low death rates are sensed for specific microorganisms of Gram-negative bacteria or Gram-positive [67, 68].
Fig. 6 Antibacterial activities of Sn-doped $\mathrm{TiO}_{2}$ toward (i) Staphylococcus Aureus; (ii) Escherichia coli: The wells a, b, and c contained $\mathrm{Sn}$-doped $\mathrm{TiO}_{2}$ samples with $1 \%, 3 \%$, and $5 \%$ Sn doping, respectively

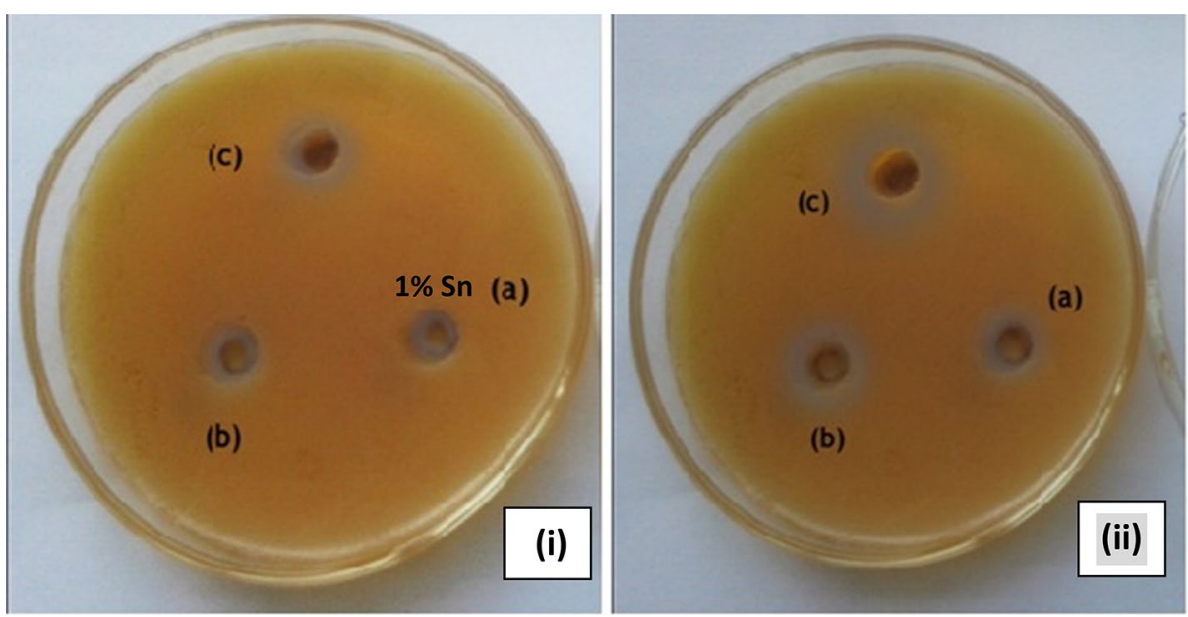



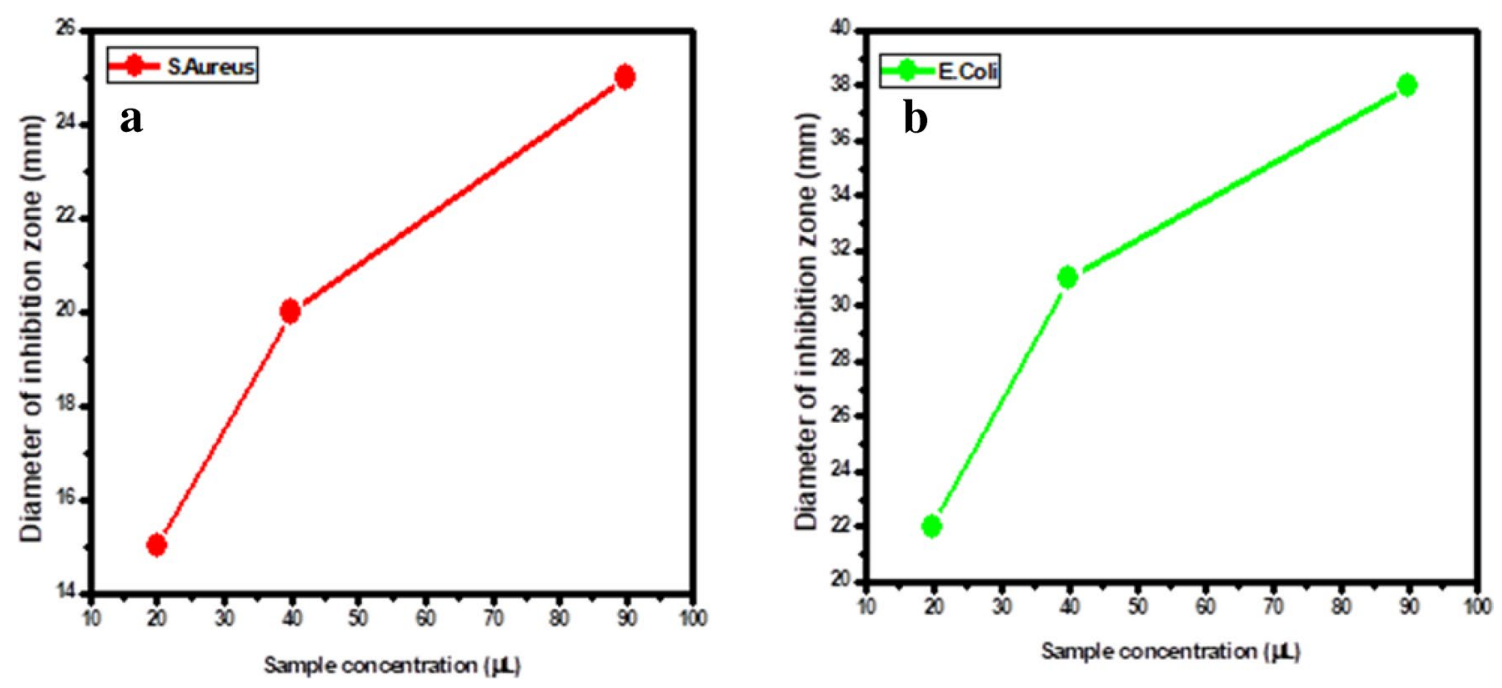

Fig. 7 Sample concentration $V s$ inhibition zone diameter for a $S$. Aureus and b E.coli

\section{Conclusion}

Sn-doped $\mathrm{TiO}_{2}$ thin films with different doping percentages are deposited by the dip coating method. A systematic investigation on the properties of the prepared films reveals an increase in crystallite size from $3.27 \mathrm{~nm}$ to $7.75 \mathrm{~nm}$ with increasing dopant concentration. Doping $\mathrm{Sn}$ into $\mathrm{TiO}_{2}$ lattice has resulted in decrease in band gap kinetic value. Also, a reduction of bandgap with increasing doping percentage is evident as the bandgap of the prepared films reduce from $3.63 \mathrm{eV}$ to $3.05 \mathrm{eV}$ when the dopant percentage is increased from 1 to $5 \%$, respectively. The FTIR analysis indicates the presence of Sn-O-Sn, $\mathrm{Ti}-\mathrm{O}-\mathrm{Ti}$, and $\mathrm{Ti}-\mathrm{O}-\mathrm{Sn}$ bonds in the sample. This confirms the effective doping of $\mathrm{Sn}$ into $\mathrm{TiO}_{2}$ matrix. The higher intensity emission peaks of PL reveal the presence of more oxygen vacancies in the sample doped with higher concentration of $\mathrm{Sn}$. On comparison of the antibacterial property of Sn-doped $\mathrm{TiO}_{2}$ for different concentrations toward the different bacterial strains, the sample exhibits better reactivity toward Gram-negative bacterial strains such as Escherichia coli (E.coli).

\section{References}

1. P.K. Stoimenov, R.L. Klinger, G.L. Marchin, K.J. Klabunde, Langmuir 18, 6679-6686 (2002)

2. D. Suresh, P.C. Nethravathi, M.A. Pavan Kumar, H. Raja Naika, H. Nagabhushana, S.C. Sharma, Mater. Sci. Semiconduct. Process. 40, 759-765 (2015)

3. S. Sathiyavimal, S. Vasantharaj, D. Bharathi, M. Saravanan, E. Manikandan, S.S. Kumar, A. Pugazhendhi, J. Photochem. Photobiol. B, Biol. 188, 126-134 (2018)
4. M. Isah, M.H. Asraf, N.A.N.N. Malek, K. Jemon, N.S. Sani, M.S. Muhammad, M.F.A. Wahab, M.A.R. Saidin, J. Environ. Chem. Eng. 8(2), 103545 (2020)

5. F. Arpanahi, B.M. Goodajdar, J. Inorg. Organomet. Polym. Mater. 30, 2572-2581 (2020)

6. F. Chioma, C.U. Ibeji, O. Okpareke, J. Mol. Struct. 121, 128017 (2020)

7. S. Shamaila, A. Khan, L. Sajjad, N. Ryma, Appl. Mater. Today 5, 150-199 (2016)

8. H.J. Lee, S.Y. Yeo, S.H. Jeong, J.Material Sci. 38, 2199-2204 (2003)

9. R. Bhattacharya, P. Mukherjee, Adv. Drug Deliv. Rev. 60, 12891306 (2008)

10. B. Pant, M. Park, H.Y. Kim, S.J. Park, Synth Met. 220, 533-537 (2016)

11. A. George, D.M.A. Raj, A.D. Raj, A.A. Irudayaraj, J. Arumugam, M. Senthilkumar, H.J. Prabu, S.J. Sundaram, N.A. Al-Dhabi, M.V. Arasu, M. Maaza, K. Kaviyarasu, Surfaces Interfaces 21:100761(2020)

12. B. Pant, P.S. Saud, M. Park, S.J. Park, H.Y. Kim, J. Alloys Compd. 671(25), 51-59 (2016)

13. B. Pant, M. Park, J.H. Lee, H.Y. Kim, S.J. Park, J. Colloid Interface Sci. 496(15), 343-352 (2017)

14. D.M.A. Raj, A. George, A.D. Raj, A.A. Irudayaraj, X. Venci, J. Arumugam, S.J. Sundaram, H.J. Prabu, Mater. Today Proc. 36, 504-508 (2021)

15. L. Visai, L.D. Nardo, C. Punta, L. Melone, A. Cigada, M. Imbriani, C.R. Arciola, Int. J. Artif. Organs 34, 929-946 (2011)

16. T. Lopez, G. Jardon, E. Gomez, A. Gracia, A. Hamdan, J. Luis Cuevas, P. Quintana, O. Novaro, Mater. Sci. Eng. 4(6), 1-6 (2015)

17. M.S. Hassan, T. Amna, A. Mishra, S.I. Yun, H.C. Kim, H.Y. Kim, M.S. Khil, J. Biomed. Nanotechnol. 8, 394-404 (2012)

18. Z. Jing, D. Guo, W. Wang, S. Zhang, W. Qi, B. Ling, Solid State Sci. 13, 1797-1803 (2011)

19. E.S. Tuchina, V.V. Tuchin, Laser Phys. Lett. 7, 607-612 (2010)

20. B. Pant, M. Park, S.J. Park, Coatings 9, 613 (2019)

21. P. Muranyi, C. Schraml, J. Wunderlich, J. Appl. Microbiol. 108, 1966-1973 (2010)

22. S. Bonetta, S. Bonetta, F. Motta, A. Strini, E. Carraro, AMB Express 59, 2-8 (2013)

23. M. Faure, F. Gerardin, J.C. Andre, M.N. Pons, O. Zahraa, J. Photochem. Photobio. A 222, 323-329 (2011) 
24. F. Sayilkan, M. Asiltürk, N. Kiraz, E. Burunkay, E. Arp, H. Sayilkana, J. Hazard. Mater. 162, 1309-1316 (2009)

25. C. Wei, W.Y. Lin, Z. Zaina, N.E. Williams, K. Zhu, A.P. Kruzic, R.L. Smith, K. Rajeshwar, Environ. Sci. Technol. 28, 934-938 (1994)

26. A.G. Rincón, C. Pulgarin, Appl. Catal. B 51, 283-302 (2004)

27. Y. Liu, J. Li, X. Qiu, C. Water Sci Technol. 54, 47-54 (2006)

28. C. Guillard, T.H. Bui, C. Felix, V. Moules, B. Lina, P. Lejeune, C. R. Chim. 11, 107-113 (2008)

29. M.J. Wu, T. Bak, P.J. O’Doherty, M.C. Moffitt, J. Nowotny, T.D. Bailey, C. Kersaitis, Int. J. Photochem. 21, 9 (2014)

30. J. Liu, Y. Zhao, L. Shi, S. Yuan, J. Fang, Z. Wang, M. Zhang, A.C.S. Appl, Mater. Interfaces 3, 1261-1268 (2011)

31. C. Wang, T. Wang, S. Zheng, Phys. E. 14, 242-248 (2002)

32. F. Jia, J. Zhang, Y. Li, B. Yang, J. Mater. Chem. 22, 24-35 (2012)

33. A. Wanag, P. Rokicka, E.K. Nejman, J.K. Kozar, R.J. Wrobel, A.M. Szczupak, A.W. Morawski, Ecotox Environ Safety 147, 788-793 (2018)

34. D.M. Tobaldi, C. Piccirillo, R.C. Pullar, A.F. Gualtieri, M.P. Seabra, P.M.L. Castro, J.A. Labrincha, J. Phys. Chem. C 118 4751-4766 (2014)

35. D. Mitoraj, A. Janczyk, M. Strus, H. Kisch, G. Stochel, P.B. Heczko, W. Macyk, Photochem. Photobiol. Sci. 6, 642-648 (2007)

36. P.A. Charpentier, C. Chen, K. Azhie, B. Groh, M.A. Mumin, A.F. Lotus, P. Therrien, S. Mittler, J. Nanotechnology 30, 085706 (2019)

37. X. Yao, X. Zhang, H. Wu, L. Tian, Y. Ma, B. Tang, Appl Surf Sci 292, 944-947 (2014)

38. T.A. Egerton, S.A.M. Kosa, P.A. Christensen, Phys. Chem. Chem. Phys. 8, 398-406 (2006)

39. L. Zhang, Q. Gao, Y. Han, J. Mater. Sci. Technol. 32, 919-924 (2016)

40. X. Li, C. Qiu, R. Burda 1(4), 2006073 (2006)

41. U. Joost, K. Juganson, M. Visnapuu, M. Mortimer, A. Kahru, E. Nõmmiste, U. Joost, V. Kisand, AngelaIvask. J. Photochem. Photobiol. B 142, 178-185 (2015)

42. B. Abdollahi Nejand, S. Sanjabi, V. Ahmadi, Trans. F. Nanotechnol 17, 102-107 (2010)

43. F. Huang, Q. Li, G.J. Thorogood, Y.B. Cheng, J Mater Chem 22, 17128-17132 (2012)

44. S. Dhanapandian, A. Arunachalam, C. Manoharan, Appl. Nanosci. 6, 387-397 (2015)

45. Y.F.S.Y. Huang, J.P. Sang, X.W. Zou, J. Alloy. Compd. 482, 382387 (2009)

46. C.M. Firdaus, M.S.B. Rizam, M. Rusop, S.R. Hidayah, Procedia Eng. 41, 1367-1373 (2012)

47. N.A. Kyeremateng, V. Hornebecq, P. Knauth, T. Djenizian, Electrochim. Acta 62, 192-198 (2012)

48. S.M. Hassan, A.I. Ahmed, M.A. Mannaa, J. Sci. Adv. Mater. Dev. 4, 400-412 (2019)

49. D.M.A. Raj, A.D. Raj, A.A. Irudayaraj, J. Mater. Sci. Mater. Electron. 25, 1441-1445 (2014)
50. G. Nazir, M. Farooq Khan, I. Akhtar, K. Akbar, P. Gautam, H. Noh, Y. Seo, S. Hyun Chun, J. Eom, RSC Adv. 7, 16890-16900 (2017)

51. G. Nazir, M. Abdul, R. Muhammad Farooq Khan, G. Dastgeer, S. Aftab, A. Muhammad Afzal, Y. Seo, J. Eom. ACS Appl. Mater. Interfaces 10, 32501-32509 (2018)

52. G. Wang, L. Xu, J. Zhang, T. Yin, D. Han, Int. J. Photoenergy 1, 1-9 (2012)

53. Y.F. Tu, S.Y. Huanga, J.P. Sang, X.W. Zou, J. Alloys Comp. 482 , 382-387 (2009)

54. A. Arunachalam, S. Dhanapandian, C. Manoharan, J. Mater Sci. Mater Electron 27, 659-676 (2015)

55. J. Liqiang, F. Honggang, W. Baiqi, W. Dejun, X. Baifu, L. Shudan, S. Jiazhong, Appl. Catal. B 62, 282-291 (2006)

56. D. Mardare, G.I. Rusu, J. Optoelectron. Adv. Mater. 6, 333-336 (2004)

57. V.B. Koli, S.D. Delekar Shivaji, H. Pawar, J Mater. Sci. Mater. Med. 27, 177 (2016)

58. B.S. Necula, J.P.T.M. Leeuwen, L.E. Fratila Apachitei, S.A.J. Zaat, I. Apachitei, (2012) J. Duszczyk, Acta Biomaterilia, 8: 4191-4197.

59. K. Manjunath, L. Sagar Reddy, T. Jayalakshmi, V. Reddy, H. Rajanaika, G. Nagaraju, J. Mater. Res. Technol. 7, 7-13 (2018)

60. M. Hosseini, S.N.K. Abad, N.N. Ilkhechi, M. Mozammel, N. Eftekhari, Mater. Res. Express 6, 1050 (2019)

61. S. Kalaiarasi, M. Jose, J. Nanostruct Chem (2016). https://doi.org/ 10.1007/s40097-016-0213-2

62. C. Karunakaran, S. SakthiRaadha, P. Gomathisankar, Mater. Express 2, 125-134 (2012)

63. B. Panta, H.R. Panta, N.A.M. Barakat, M. Park, K. Jeon, Y. Cho, H.Y. Kim, J. Ceram 39(6), 7029-7035 (2013)

64. B. Pant, H.R. Pant, D.R. Pandeya, G. Panthi, K.T. Nam, S.T. Hong, C.S. Kim, H.Y. Kim, J. Colloids Surf. A Physicochem. Eng. 395, 94-99 (2012)

65. T. Saito, T. Iwase, J. Horie, T. Morioka, J. Photochem. Photobiol., B 14, 369-379 (1992)

66. G. Carré, E. Hamon, S. Ennahar, M. Estner, M.C. Lett, P. Horvatovich, J.P. Gies, V. Keller, N. Keller, P. Andre, Appl. Environ. Microbiol. 80(8), 2573 (2014)

67. M. Cho, H. Chung, W. Choi, J. Yoon, Appl. Environ. Microbiol. 71(1), 270 (2005)

68. A. Kubacka, M.S. Diez, D. Rojo, R. Bargiela, S. Ciordia, I. Zapico, J.P. Albar, C. Barbas, V.A.P.M.D. Santos, M.F. Garcia, M. Ferrer, Sci. Rep. 4, 4134 (2014)

Publisher's Note Springer Nature remains neutral with regard to jurisdictional claims in published maps and institutional affiliations. 


\section{Terms and Conditions}

Springer Nature journal content, brought to you courtesy of Springer Nature Customer Service Center GmbH ("Springer Nature").

Springer Nature supports a reasonable amount of sharing of research papers by authors, subscribers and authorised users ("Users"), for smallscale personal, non-commercial use provided that all copyright, trade and service marks and other proprietary notices are maintained. By accessing, sharing, receiving or otherwise using the Springer Nature journal content you agree to these terms of use ("Terms"). For these purposes, Springer Nature considers academic use (by researchers and students) to be non-commercial.

These Terms are supplementary and will apply in addition to any applicable website terms and conditions, a relevant site licence or a personal subscription. These Terms will prevail over any conflict or ambiguity with regards to the relevant terms, a site licence or a personal subscription (to the extent of the conflict or ambiguity only). For Creative Commons-licensed articles, the terms of the Creative Commons license used will apply.

We collect and use personal data to provide access to the Springer Nature journal content. We may also use these personal data internally within ResearchGate and Springer Nature and as agreed share it, in an anonymised way, for purposes of tracking, analysis and reporting. We will not otherwise disclose your personal data outside the ResearchGate or the Springer Nature group of companies unless we have your permission as detailed in the Privacy Policy.

While Users may use the Springer Nature journal content for small scale, personal non-commercial use, it is important to note that Users may not:

1. use such content for the purpose of providing other users with access on a regular or large scale basis or as a means to circumvent access control;

2. use such content where to do so would be considered a criminal or statutory offence in any jurisdiction, or gives rise to civil liability, or is otherwise unlawful;

3. falsely or misleadingly imply or suggest endorsement, approval, sponsorship, or association unless explicitly agreed to by Springer Nature in writing;

4. use bots or other automated methods to access the content or redirect messages

5. override any security feature or exclusionary protocol; or

6. share the content in order to create substitute for Springer Nature products or services or a systematic database of Springer Nature journal content.

In line with the restriction against commercial use, Springer Nature does not permit the creation of a product or service that creates revenue, royalties, rent or income from our content or its inclusion as part of a paid for service or for other commercial gain. Springer Nature journal content cannot be used for inter-library loans and librarians may not upload Springer Nature journal content on a large scale into their, or any other, institutional repository.

These terms of use are reviewed regularly and may be amended at any time. Springer Nature is not obligated to publish any information or content on this website and may remove it or features or functionality at our sole discretion, at any time with or without notice. Springer Nature may revoke this licence to you at any time and remove access to any copies of the Springer Nature journal content which have been saved.

To the fullest extent permitted by law, Springer Nature makes no warranties, representations or guarantees to Users, either express or implied with respect to the Springer nature journal content and all parties disclaim and waive any implied warranties or warranties imposed by law, including merchantability or fitness for any particular purpose.

Please note that these rights do not automatically extend to content, data or other material published by Springer Nature that may be licensed from third parties.

If you would like to use or distribute our Springer Nature journal content to a wider audience or on a regular basis or in any other manner not expressly permitted by these Terms, please contact Springer Nature at

onlineservice@springernature.com 